\title{
The effect of caffeine on osteoblast proliferation after tooth extraction in Wistar rats
}

\author{
Budi Yuwono \\ Department of Oral Surgery \\ Faculty of Dentistry Jember University \\ Jember - Indonesia
}

\begin{abstract}
Caffeine is the most well-known substance which consumed by most people daily. Behind its popularity as favorable drinks and food, this substance also known can inhibit the post extraction wound healing by decreasing the proliferation of osteoblast cells through the increase of intracellular cyclic Adenosine Mono Phosphate (cAMP). The objective of this study was done to observe the effect of caffeine intake toward the number of osteoblast cells during the wound healing of post dental extraction in Wistar's rats. This study was an experimental laboratory research and the post test-only control group design was used for the statistical evaluation. The samples used were 24 healthy 3 months old male Wistar's rats, with approximately 200 grams of body weight and devided into 4 groups. Three groups were taken and represented as a treated group $(P)$ and the rest of one group was used as a control group (KO). Caffeine diet with a dosage of $3.78 \mathrm{mg} / 100 \mathrm{ml}$ grams of body weight/cc was given for 7 days in group P1, P2 for 14 days, and 21 days in group $P 3$ and the diet was given orally using an oral sonde. Teeth extractions of the right first molar in the lower jaw were done in all groups according to the interval time had been scheduled. Seven days of post-extraction time was waiting in all groups before the sample being decapitated for further histological examination in the post extracted sites. A Hematoxillin and Eosin staining was used and the number of osteoblast cells were counted under light microscopy with 400 times magnification. One-way ANOVA and Least Significant Difference (LSD) test were used for the statistical evaluation. The result of the study shown a significant decrease of the number of osteoblast cells in caffeine consumed group of 7, 14, and 21 days observed ( $p<0.05)$. This study conclude that the duration time of caffeine consumed had been interfered significantly with the osteoblast cell proliferation during the wound healing after teeth extractions in Wistar's rats.
\end{abstract}

Key words: caffeine, osteoblast, healing

Correspondence: Budi Yuwono, c/o: Bagian Ilmu Bedah Mulut, Fakultas Kedokteran Gigi Universitas Jember. Jln. Kalimantan I No. 58 Jember 68121, Indonesia.

\section{INTRODUCTION}

Caffeine is the most well-known substance which is consumed by approximately $80 \%$ people in the world. We find this substance is in coffee, tea, chocolate, coke, ice cream, yogurt, and orange juice. Caffeine is widely known as a nerve stimulant and it is assumed to enhance intelligence. ${ }^{1}$ Although caffeine is popular as favorable drinks and food that consumed by children and adults daily, caffeine can inhibit wound healing process. Based on our experience, we found many patients with decreasing of wound healing after dental extraction. This phenomenon urged us to study further the role of caffeine in wound healing process.

Kamagata et al. ${ }^{2}$ found that caffeine inhibit osteoblast proliferation (in vitro) through the increasing of cyclic Adenine Mono Phosphate (cAMP) as the cause of intracellular phosphodiesterase inhibition. Furthermore, it was reported that caffeine have a role in bone metabolism.

Wound healing process in lacerated tissue is initially responded by an inflammation. The first change is in the vascular stage by vasodilatating, extravasating and exudating the wounded area. The release of Prostaglandin $\mathrm{E}_{2}\left(\mathrm{PGE}_{2}\right)$ as the inflammation mediator in wound area stimulate production of colagenase which trigger degradation of collagen and other potent factor for bone resorption, and also increase osteoclastic activity. ${ }^{3}$ Kamagata et al. ${ }^{2}$ reported that the increased $\mathrm{PGE}_{2}$ alone could inhibit osteoblast proliferation through intracellular cAMP increment (in vitro).

The released of $\mathrm{PGE}_{2}$ in wound area that accompanied by certain doses of caffeine intake, could inhibit wound healing. Kamagata et al. ${ }^{2}$ had proved that the combination effect of caffeine and $\mathrm{PGE}_{2}$ could inhibit osteoblast proliferation significantly (in vitro). More over, it was reported that caffeine intake could increase $\mathrm{PGE}_{2}$ production and $0.1 \mathrm{mM} / \mathrm{ml}$ caffeine could enhance $\mathrm{PGE}_{2}$ production.

Based on the explanation that caffeine intake at certain doses and $\mathrm{PGE}_{2}$ can inhibit osteoblast proliferation and increase osteoclast activity in bone resorption and remodeling mechanism, it is assumed that caffeine is influential towards the osteoblast number of post tooth extraction. 
The aim of this study is to evaluate the effect of caffeine on the number of osteoblasts after tooth extraction wound healing. Hopefully this study may develop the post tooth extraction wound healing theory, give information about substances which can inhibit the wound healing process and also give information to patients who have high risk to osteoporosis, diabetes mellitus, old age, stress and PMN dysfunction caused by excessive caffein intake.

\section{MATERIALS AND METHODS}

This study was an experimental laboratory research with a random PosT Test-only-control-group-design. The samples were 24 healthy 3-month-old male Wistar's rat, with \pm 200 grams of body weight and divided into 4 groups (6 rats each). One group was control group with no caffeine treated. Three groups (P1, P2, and P3) were treated with $3.78 \mathrm{mg} / 100 \mathrm{gr}$ of body weight/cc per oral caffeine (MERC, Germany). Each group was placed in a different cage and some food ad libitum were given. In control group: the right molar in the lower jaw was extracted and was let live for 7 days. Caffeine was given for 7 days in group $\mathrm{P}_{1}, \mathrm{P} 2$ for 14 days and 21 days in group 3, then the right molar in the lower jaw was extracted and was let live for 7 days.

To obtain the right lower jaw, all samples were mortified with ether anesthetic. Each right lower jaw was soaked to $10 \%$ formaldeyde to prepare an object/preparat of right lower jaw bone with the routine procedure, decalcification, dehydration and embedding. A sagittal section was prepared showing post extraction dental socket. The sample was 7 section micrometer, painted and colored with a Hematoxillin \& Eosin routine dye, then with a light microscope of 400x enlargement, the osteoblast cells were counted in the post extraction socket. The data was analyzed with One-way ANOVA and Least Significant Difference (LSD) tests. The research was conducted at the biochemical laboratory, Tropical Disease Center-Airlangga University and at the pathologic laboratory of Dr.Soetomo General Hospital in May until July 2005.

\section{RESULTS}

The average number of osteoblasts in post-extraction wound healing could be seen in figure 1 . There was an average difference of the number of osteoblast in P1 (7 days), P2 (14 days) and P3 (21 days) as well as in the control group.

To determined the differences of the osteoblast numbers in 4 groups, a statistical test One-way ANOVA was performed. The result have shown a significant difference in group of control, P1 , P2, and P3 ( $<<0.05)$. To find out the difference of osteoblas numbers among groups, LSD test with margin of error $(\alpha=0.05)$ was performed. The result showed a significant decrease of the number of osteoblasts in all of the group $(\mathrm{p}<0.05)$ as seen on table 1 .

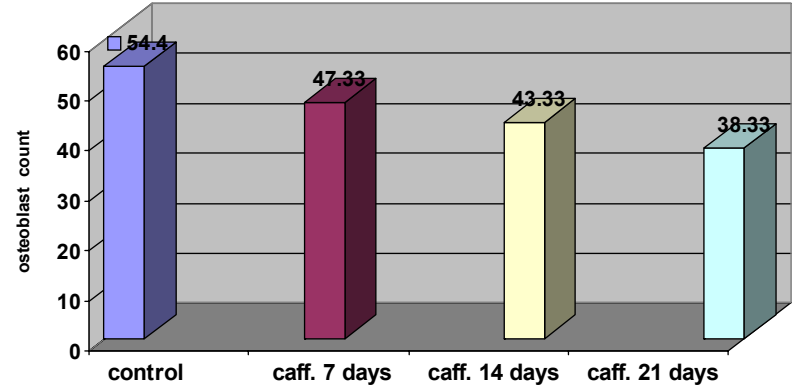

Figure 1. Block diagram of the average osteoblast number in the control group, 7 days caffeine, 14 days caffeine and 21 days caffeine.

Table 1. LSD Analysis of inter group sample with degree of error 0.05

\begin{tabular}{|c|c|c|c|c|}
\hline & Control & $\begin{array}{l}7 \text { days } \\
\text { caffeine }\end{array}$ & $\begin{array}{l}14 \text { days } \\
\text { caffeine }\end{array}$ & $\begin{array}{l}21 \text { days } \\
\text { caffeine }\end{array}$ \\
\hline $\begin{array}{l}\text { Control } \\
7 \text { days caffeine } \\
14 \text { days caffeine } \\
21 \text { days caffeine }\end{array}$ & & $\mathrm{p}=0.001^{*}$ & $\begin{array}{l}\mathrm{p}=0.001^{*} \\
\mathrm{p}=0.038^{*}\end{array}$ & $\begin{array}{l}\mathrm{p}=0.001 * \\
\mathrm{p}=0.001 * \\
\mathrm{p}=0.011 *\end{array}$ \\
\hline
\end{tabular}

Explanation: $*=$ significant with $\alpha=0.05$

\section{DISCUSSION}

Based on many theories presented previously, it revealed that caffeine intake could decrease osteoblast cells activity due to the increased of $\mathrm{PGE}_{2}$ which was stimulated by the enhancement of intracellular cAMP.

Caffeine will be absorbed by intestines, distributed to all body parts including the nerve-circuit. The nerve stimulant mechanism by caffeine was still unclear, but it was found that the methyl compound of caffeine substructure detached itself when interacted with cell membrane. The methyl compound diffused between two membrane layers, adding methyl component to its fat, resulting a change in surface tension. The decreased of surface tension made the membrane damped by water and soluble substance easily, until the ions could easy to diffuse and push ion formation effectively. It caused a more active intersynapse exitation. The active exitation is the electrical simulator for the release of central neurotransmitter like Gamma Amino Butirate Acid (GABA) or choline acethyl which is make strong post synaptic respond to stimulate the central nervous system actively. ${ }^{4}$

The stimulation of the central nervous system trigger the cell surface to release $A_{2}$ phospholipase enzyme. The $\mathrm{A}_{2}$ phospholipase pushed ahead the release of arachidonic acid from the lipid membrane and converse it to $\mathrm{PGE}_{2}$ cyclic derivative through the work of cyclo-oxygenase. The $\mathrm{PGE}_{2}$ give a certain effect to the body i.e. inhibiting electrolyte resorption on proximal tubulus and make the entering water was not re-absorbed, thus causing a constant excretion quantity, yielding a tendency to diuresis. ${ }^{5}$ 
Lerner and Mellstrom ${ }^{6}$ reported that caffeine has a role on bone resorption in relation to calsium. Caffeine could raise the spontaneous detachment of calsium mineral from neonatal mouse calvarian bone (in vitro). A certain dose of caffeine could trigger the raise of calsium detachment from bone, which could stimulate bone resorption action through cAMP cyclase adenilate system.

The increased of $\mathrm{PGE}_{2}$ not only bring a diuretic effect, it also directly influence osteoclastic differentiation through a raising activity of mononucleat precursor to become mature osteoclast. Beside this activity, $\mathrm{PGE}_{2}$ also increase mature osteoclast activity to re-absorb bone and to form extracellular matrix. ${ }^{7}$ This effect was related to the increased of cAMP inside the bone through activated cyclase adenilate that increased the number, activity and mobilization of osteoclast. ${ }^{8}$

High $\mathrm{PGE}_{2}$ level also decrease osteoblast differentiation, by specific receptor which is raise phosphodiesterase enzyme activity in osteoblast. Phosphodiesterase enzyme stimulated cAMP degradation, lowering cAMP content, resulting a decrease in osteoblast activity. ${ }^{7}$ Basically, $\mathrm{PGE}_{2}$ influenced bone changes to become more effective.

The increase of $\mathrm{PGE}_{2}$ level by caffeine that influenced the escalation of osteoclasts activity will stimulate bone resorption. This statement was in accord with Kamagata et al., ${ }^{2}$ that $0.1 \mathrm{mM} / \mathrm{ml}$ caffeine could already increase $\mathrm{PGE}_{2}$ production that inhibit osteoblast activity. $\mathrm{PGE}_{2}$ also activated osteoclast which was crucial in bone resorption.

Beside its popularity as favorable drinks and food, caffeine was also assumed to inhibit wound healing process. Caffeine inhibited osteoblast cell proliferation (in vitro), through the increased level of cAMP caused by intracellular phosphodiesterase. ${ }^{2}$ The increased cAMP level inhibited osteoblast proliferation. Moreover, it was reported that caffeine influence bone metabolism.

Wound healing process in lacerated tissue is initially responded by an inflammation. The first change is in the vascular stage by vasodilatating, extravasating_and exudating the wounded area. The release of Prostaglandin $\mathrm{E}_{2}$ as the inflammation mediator in wound area, could stimulate the production of collagenase enzyme production which could trigger collagen dehydration, other potent factor for bone resorption and could increase osteoclastic activity. ${ }^{3}$ Kamagata et al. ${ }^{2}$ reported that the increased $\mathrm{PGE}_{2}$ alone inhibit osteoblast proliferation through intracellular cAMP increment (in vitro).

The released $\mathrm{PGE}_{2}$ in wound area accompanied by certain doses of caffeine intake could inhibit wound healing. A study done by Kamagata et $a l .^{2}$ had proved that the combination effect of caffeine and $\mathrm{PGE}_{2}$ could inhibit osteoblast proliferation (in vitro). significantly Moreover, it was reported that caffeine intake could increase PGE $_{2}$ and $0.1 \mathrm{mM} / \mathrm{ml}$ caffeine could already increase $\mathrm{PGE}_{2}$ production.

Grounded on the result of this study (in vitro), it has been proven that caffeine can decline significantly the number of osteoblast cell ( $\mathrm{p}<0.05)$ on 3 groups of 7,14 , and 21 days caffeine diet. The longer the caffeine intake take place, the more decreased of osteoblast cell numbers. This fact strengthen the assumption that caffeine both in vitro and in vivo is involved in bone mechanism, resorption, apposition on wound healing process.

This research demonstrated that chronic caffeine intake has a risk towards the decline of osteoblast cells. The duration time of caffeine consumed had been interfered significantly with the osteoblast cell proliferation during the wound healing after teeth extractions in Wistar's rats.

\section{REFERENCES}

1. Fen S. Kafein sebuah penenang semu. Jakarta: Penerbit Pustaka Utama; 1993. p. 78-9.

2. Kamagata Y, Mitsuhiro C, Gina, Saltzman MJ. Combined effects of $\mathrm{PGE}_{2}$ and caffeine on alveolar resorption. J Periodontology 1999 March; 15:234-38.

3. Nakano K, Ohishi M, Ogawa Y, Ohba T, Kido J. Protaglandin E2 inhibit alveolar bone resorption in experimental periodontitis in Hamsters. J Periodontology 1998 March; 34:108-11.

4. Ungaro, Feas JKRN, Marry GR, Casey B. The effect of caffeine and alcohol on hepatic cellular. J Medical \& Health 1997 July; 34:65-9.

5. Guyton. Textbook of human psychology. London: Mosby-Year Book Inc; 1995. p. 711-15.

6. Lerner UH, Mellstrom D. Caffeine has the capacity to stimulate calcium release in organ culture of neonatal mouse calvaria. University of Umea, Sweden. Calcif Tissue Int; 1992. p. 424-28.

7. Schwatz ZJ, Goultschin DD, Dean, Byan BD. Mechanism of alveolar bone destructions of periodontitis. J Endodontic 1997 December; 22:677-80.

8. Offenbecher S, Heasman, Collins JG. Modulation of host $\mathrm{PGE}_{2}$ secretions as a determinant of periodontal disease expression. J Periodontology 1993 August; 64:432-44. 